\title{
Rights of Nature Versus Conventional Nature Conservation: International Lessons from Australia's Tarkine Wilderness
}

\author{
Draft; pre-published version
}

Final version in Environmental Policy and Law, Vol. 51 (2021): pp.159-173

\author{
Benjamin J. Richardson and Nina Hamasaki \\ Faculty of Law, University of Tasmania
}

\begin{abstract}
The rights-of-nature model is gaining traction as an innovative legal approach for nature conservation. Although adopted in several countries, it remains in its infancy, including in Australia. An important research question is whether rights of nature will offer superior environmental outcomes compared to traditional nature conservation techniques including creation of protected areas. This article investigates that question through a case study of the Tarkine wilderness, in the Australia state of Tasmania. It first identifies key lessons from existing international experience with affirmation of rights of nature, such as in New Zealand and Ecuador. The article then explores how rights of nature could apply in Australia's Tarkine region and their value compared to existing or potential protected areas and other nature conservation measures under Australian or Tasmanian law. Affirming rights of nature represents a major conceptual shift in how people via the law relate to the natural world, but whether the model offers practical benefits for nature conservation depends on a variety of conditions, in addition to the need to address broader societal drivers of environmental degradation.
\end{abstract}




\section{INTRODUCTION}

An emerging new legal model that is gaining international attention is the designation of the natural world as a rights-bearing stakeholder. ${ }^{1}$ According to one proponent, it 'transform[s] the status of nature from being regarded as property" to having rights "to exist, thrive and evolve". ${ }^{2}$ For most legal systems around the world, the notion of ecosystems or individual species having legal rights for no other purpose than to protect and preserve their health and wellbeing is unorthodox. ${ }^{3}$ The endowing of nature with a legal personality is not so controversial in one respect given that legal status for inanimate structures already exists in the legal personification of a corporation. 4 More controversial is how rights of nature potentially redefine humanity's relationship with the non-human world. Under the aegis of theories of "Earth jurisprudence" and "wild law", 5 affirming nature's rights challenges the current legal position of managing nature instrumentally in service of human needs. Whether nature rights can achieve such a reorientation in practice is not assured, as the history of environmental law shows many reforms fall well short of their aspiration.

This article evaluates the rights-of-nature model in Australia. Unlike existing literature, our approach has two novel dimensions: (1) it assesses the model's potential value relative to conventional protected areas - the traditional tool for nature conservation; and (2) explores its potential application through a case study, namely the Tarkine wilderness in the Australian state of Tasmania. Holding Australia's largest tract of temperate rainforest, much of the Tarkine - or takayna, as Aboriginal people know it - is unprotected and open to exploitation for forestry and mining. The case study offers a pragmatic assessment of how nature rights might work in practice, and compare to existing options of a new national park or extension of the Tasmanian

${ }^{1} \mathrm{G}$. Samuel, Independent Review of the EPBC Act: Interim Report. (Commonwealth of Australia, 2020).

2 Australian Earth Laws Alliance, "Rights of Nature", www.earthlaws.org.au/what-we-dointernational.

${ }^{3}$ P. Burdon, "Earth Jurisprudence and the Murray Darling: The Future of a River" (2012) 37(2) Alternative Law Journal 82.

${ }^{4}$ C. Stone "Should Trees Have Standing - Towards Legal Rights for Natural Objects' (1972) 45 Southern California Law Review 450, 452.

${ }^{5}$ C. Cullinan, Wild Law A Manifesto for Earth Justice (Green Books, Devon, 2003). 
Wilderness World Heritage Area (TWWHA). For readers unfamiliar with nature rights, we introduce its conceptual basis and briefly canvass its implementation elsewhere to date before turning to the case study. We conclude that rights of nature ostensibly offer material benefits relative to conventional protected areas, but remain prone to some failings in implementation as for environmental law generally.

\section{WHAT ARE RIGHTS OF NATURE?}

Proposals for rights of nature feed off debates about some fundamental limitations of existing environmental laws. ${ }^{6}$ It is not simply that environmental conditions in many countries including Australia have worsened over recent decades. ${ }^{7}$ Critics suggest that a deeper malaise is rooted in the anthropocentric worldview that fuels unsustainable exploitative practices. ${ }^{8} \mathrm{~A}$ structural shift in law towards a nature-centric paradigm is thus recommended in contrast to approaches that predicate nature conservation on cost-benefit analysis, property tenure and other factors that prioritise human needs. A cognate movement for animal rights draws on related conceptual foundations. ${ }^{9}$

Nature rights has both spatial and temporal dimensions. They affirm the intrinsic values of specific natural places, such as a river or forest, as well as their selfcreative capacities to regenerate and evolve over time. ${ }^{10}$ They build on a normative worldview of the biosphere's interconnectedness and ethical imperative to respect the ecological integrity of the natural world. Personifying nature may be relatively novel to Western legal systems but has long pedigree in some Indigenous people's cultures

${ }^{6}$ E.g. B.J. Richardson, Time and Environmental Law: Telling Nature's Time (Cambridge University Press, 2018).

${ }^{7}$ G. Readfearn, "Shocking: Wilderness the Size of Mexico Lost Worldwide in Just 13 Years, Study Finds", The Guardian, 19 September 2020, www.theguardian.com/environment/2020/sep/19, H. Briggs, "Wildlife in "Catastrophic Decline" Due to Human Destruction", Scientists Warn", BBC News, 10 September 2020, www.bbc.com/news/science-environment-54091048.

${ }^{8}$ E.g., P. Burdon, "Earth Jurisprudence and the Project of Earth Democracy", in M. Maloney and P. Burdon (eds) Wild Law in Practice (Routledge, 2014) 19.

9 See, e.g., J.P. Manalich R., "Animalhood, Interests and Rights" (2020) 11(2) Journal of Human Rights and the Environment 156.

${ }^{10}$ L. Westra, "Ecological Integrity" in C. Mitcham (ed), Encyclopedia or Science, Technology and Ethics (Macmillan Reference, 2005) 574, 575. 
that recognise nature's familial qualities. ${ }^{11}$ Also, some Eastern religions such as Hinduism and Buddhism postulate sacredness in elements of the natural world. ${ }^{12} \mathrm{An}$ important philosophical debate is whether nature has "intrinsic" values, and thus rights, given such values and rights are defined or interpreted by humans. ${ }^{13}$ This debate need not detain us, as our focus is the formulation and implementation of such rights in the legal system and their comparison to other options for nature conservation.

In legal circles, the notion that nature has rights was influenced by Christopher Stone's seminal thesis: "Should Trees have Standing?'" 14 Stone unpacked the prevailing condition of the natural world as lacking rights or legal personality under Western law, and its treatment as "property", thereby making analogies with how slaves were treated. He argued that natural places and processes should have rights to maintain their existence and health, and therefore standing to defend those rights in legal forums. In turn, recognising nature's rights in our legal system should help people to value nature in its own right, instead of it being just a resource for human needs.

The Australian Panel of Experts on Environmental Law (APEEL), identified several legal dimensions of nature rights. ${ }^{15}$ One recognises natural places as having a legal personality, meaning "nature" has rights and is a material stakeholder in governance decisions that may impact it. ${ }^{16}$ Secondly, this personality can be articulated via an institution, such as a guardian or trustee acting on behalf of the beneficiary. ${ }^{17}$ Thirdly, rights of nature afford protection, and where necessary restorative action, against any injury caused to the health, wellbeing and integrity of the natural place in question. Finally, although the notion is that "nature" itself is given legal personhood, such rights

${ }^{11}$ A. Pellizon "Earth Laws, Rights of Nature and Legal Pluralism" in M. Maloney and P. Burdon (eds), Wild Law in Practice (Routledge, 2014) 178.

${ }^{12}$ R.S. Gottlieb (ed), This Sacred Earth: Religion, Nature and Environment (Routledge, 2004).

${ }^{13}$ See, e.g., R. Sandler, "Intrinsic Value, Ecology and Conservation" (2012) 3(10) Nature Education Knowledge 4, J.J. Piccolo,"'Intrinsic Values in Nature Objective Good or Simply Half of an Unhelpful Dichotomy?" (2017) 37 Journal for Nature Conservation 8.

14 Stone, supra note 4, 450.

${ }^{15}$ Australian Panel of Experts on Environmental Law, Democracy and the Environment (Technical Paper 2017) 30.

${ }^{16}$ Stone, supra note $4,458$.

${ }^{17}$ E. O'Donnell, and J. Talbot-Jones. "Creating Legal Rights for Rivers: Lessons from Australia, New Zealand, and India" (2018) 23(1) Ecology and Society 7. 
are not normally associated with the biosphere at large but rather specific elements of it, such as a river, mountain or ecosystem.

The affirmation of nature's rights does not necessarily entail banning all economic development or other human activity in a beneficiary area. ${ }^{18}$ Rather, it restricts behaviour that threatens the vitality and integrity of the protected place, and creates access to justice and remedies for violations. Recognition of the legal personhood in a natural place or object is unlikely in itself to be sufficient to redefine humankind's relationship with nature however; rather, it is a prerequisite to reforming environmental laws, including the machinery for protecting an area's natural values, managing conflicts between human interests and the best interest of natural places, and providing for representation of natural areas in decision-making forums including courts. $^{19}$

Legal rights of nature have influenced judicial decisions, legislation and constitutional reforms in some countries already. ${ }^{20}$ The following section briefly canvasses some legal developments.

\section{NATURE RIGHTS IN PRACTICE}

\section{New Zealand}

New Zealand is a pioneer in nature rights. The country's former national park, Te Urewera comprising 212,00 hectares of native forests, mountains and lakes, has since 2014 legally owned itself. Under its 2014 founding legislation, Te Urewera is a legal entity that "has all the rights, powers, duties, and liabilities of a legal person ". ${ }^{21}$ The Te Urewera Board created by the legislation manages and acts on behalf of Ta Urewera to protect its values. ${ }^{22}$ The Board comprises three representatives from the government and the Tūhoe Indigenous community. The Act recognises Te Urewera for

\footnotetext{
${ }^{18}$ Stone, supra note $4,457$.

${ }^{19}$ O'Donnell, and Talbot-Jones. supra note 17,

${ }^{20}$ E. Fitz Henry, "Decolonising Personhood" in M. Maloney and P. Burdon (eds) Wild Law in Practice (Routledge, 2014) 133, 134.

${ }^{21}$ Te Urewera Act 2014 (NZ) section 11.

${ }^{22}$ Ibid, section 16.
} 
its intrinsic value, its beauty, its cultural, spiritual and natural values, its indigenous ecological systems and its importance to the Tūhoe. Another New Zealand example is Te Awa Tupua - "an indivisible and living whole comprising the Whanganui River from the mountains to the sea, incorporating its tributaries and all its physical and metaphysical elements", ${ }^{23}$ as established under the Te Awa Tupua (Whanganui River Claims Settlement) Act 2017. Like for Te Urewera, this law grants legal personality to the Whanganui River, and prescribes trustee governance for stewardship of its natural and cultural values.

Both the foregoing represent settlements between the Māori and the Crown to redress colonial wrongs and restore the Māori relationship with their natural environment. ${ }^{24}$ Katherine Sanders, a New Zealand academic, describe the results of these laws as "a symbolic reframing of relationships between people and the environment' as well as providing "new frameworks for relationships between people", in particular between Indigenous and settler peoples. ${ }^{25}$ The statutes address long standing injustices to the Māori by the Crown ${ }^{26}$ and symbolise reconciliation to uphold the principles of the Treaty of Waitangi 1840 that was moribund until the 1970s. The integration of the rights and interests of Indigenous peoples with nature right laws, has been an important factor regarding "guardianship" over natural places. ${ }^{27}$

Significant and beneficial overlaps between Indigenous concepts of a "personified natural world" and the nature rights models may exist. The New Zealand experience thus has relevance to Australia, with its own Indigenous peoples, because it suggests that nature rights can accommodate human (Indigenous people) interests in the environment, and that nature is not separate but a cultural landscape, layered with human history. Indigenous environmental practices are not always sympathetic

\footnotetext{
${ }^{23}$ Te Awa Tupua (Whanganui River Claims Settlement) Act 2017, section 12.

${ }^{24}$ K. Sanders, "Beyond Human Ownership?" Property, Power and Legal Personality for Nature in Aotearoa New Zealand" (2018) 30(2) Journal of Environmental Law 207, 210.

25 Ibid,

26 K. Warne, "A Voice for Nature" National Geographic, www.nationalgeographic.com/culture/2019/04/maori-river-in-new-zealand-is-a-legal-person..

${ }^{27}$ APEEL, supra note $15,31$.
} 
to natural values, ${ }^{28}$ but their practices are usually far more benign than that of industrial society.

\section{Ecuador}

Ecuador was an early mover in recognising nature rights. Its national constitution of 2008, declares; "Nature, or Pacha Mama, where life is reproduced and occurs, has the right to integral respect for its existence and for the maintenance and regeneration of its life cycles, structure, functions and evolutionary processes". ${ }^{29}$ The constitution further mandates that any person can enforce the latter provision, ${ }^{30}$ and it gives nature a right to be restored. ${ }^{31}$ In a country blighted by mining, deforestation and oil pollution, these constitutional provisions are potentially momentous.

However, government authorities and courts have struggled to develop practical machinery and compliance mechanisms to give effect to this constitutional prescription. The first ruling of an Ecuadorian court on the rights of nature involved a case brought by concerned citizens against a public contractor constructing a road along the Vilcabamba River, using dynamite and heavy machinery. The court ruled the river's rights had been violated, although it did not ban road construction; instead, the project could continue so long as environmental standards from the Ministry of Environment were followed. ${ }^{32}$ But when the contractor was alleged to have persisted in violating the court's ruling, the environmental groups that brought the initial case were unable to continue because of lack of funds - a situation that highlights both the need to rely on conventional environmental standards to define the content of nature's rights and the barrier to enforcing the rights when no entity is required to protect those rights or is inadequately resourced.

${ }^{28}$ T. Flannery, The Future Eaters. An Ecological History of the Australasian Lands and Peoples (New Holland Publishers, 1994).

29 Constitution of the Republic of Ecuador 2008, article 71, see https://pdba.georgetown.edu/Constitutions/Ecuador/english08.html.

$30 \mathrm{Ibid}$, article 72.

${ }^{31}$ Ibid, article 73.

32 Ruling by the Ecuadorian Sala Penal de la Corte Provincial. Protection Action. Ruling Number No. 11121-2011-0010. Casillero N0. 826. 30 March 2011. 
In a major case launched in 2020, environmental groups have petitioned the Constitutional Court to halt mining concessions in the Los Cedros forest reserve, a renowned biodiversity hotspot. The Earth Law Center and Global Alliance for the Rights have asked the Court to enforce the constitutional rights of nature. Affirmation of their priority over mining would not only safeguard Los Cedros's 4,800 hectares of forest from mining, but could provide a precedent to safeguard all the 186 supposedly protected forest reserves in Ecuador, totalling 2.4 million hectares. ${ }^{33}$

\section{Other International Precedents}

The rights of nature movement is becoming an international phenomenon, as legislatures and courts emulate precedents established in the foregoing.

Bolivia's 2009 constitution provides that "Everyone has the right to a healthy, protected, and balanced environment', a right whose exercise is granted to not only people but "'other living things". ${ }^{34}$ The 2010 Law of the Rights of Mother Earth provides: "Mother Earth takes on the character of collective public interest. Mother Earth [...] including human communities, are entitled to all the inherent rights recognized in this Law". ${ }^{35}$ Article 7 elaborates that these rights include to the diversity of life, water, clean air, pollution-free living and restoration. An Office of Mother Earth was established to promote compliance with the legislation. A revised and expanded version of this law was enacted in $2012 .{ }^{36}$

In India, the Ganges and Yamuna rivers were affirmed by a court as having legal rights. Judges Rajeev Sharma and Alok Singh of the Uttarakhand High Court declared that these rivers are "legal and living entities having the status of a legal person with

${ }_{33}$ See Reserva Los Cedros, https://loscedrosreserve.org/los-cedros-court-case-date-announced.

34 Bolivia's Political Constitution of the State 2009, www.constituteproject.org/constitution/Bolivia_2009.pdf.

${ }^{35}$ Bolivian Law 071, Ley de Derechos de la Madre Tierra, 21 December 2010, article 5. For an English translation, see www.worldfuturefund.org/Projects/Indicators/motherearthbolivia.html.

${ }^{36}$ Framework Law of Mother Earth and Integral Development for Living Well (La Ley Marco de la Madre Tierra y Desarrollo Integral para Vivir Bien); Law 300) on October 15, 2012. 
all corresponding rights, duties and liabilities". ${ }^{37}$ Drawing on the Indian Supreme Court's jurisprudence regarding personhood of Hindu deities, the Uttarakhand judges found legal sentience in the holy rivers analogous to New Zealand lawmakers' affirmation that the Whanganui River is "a spiritual and physical entity" with an "inalienable connection with" its traditional Indigenous custodians. ${ }^{38}$ However, a setback occurred in March 2017 when India's top court overturned this decision, ruling that the venerated Ganges and Yamuna rivers cannot be considered "living entities" as the precedent was legally unsustainable and impractical to implement. ${ }^{39}$ The initial recognition of the legal personhood of the Indian rivers was a judicial decision, without the community consultation and analysis of how the new legal status would operate in practice, in contrast to the New Zealand approach built on an eight-year stakeholder consultation process with detailed consideration of future implementation.

On the other hand, Bangladesh's highest court in July 2019 granted all the country's rivers legal personhood, with the hope to reduce their further impairment from pollution and other human impacts. ${ }^{40}$ The court appointed Bangladesh's National River Conservation Commission, a government agency, as the legal guardian of rivers and empowered it to sue any polluters. It remains to be seen whether the new legal status of Bangladesh's rivers will yield any practical benefit given that the country already has in place water pollution regulations.

Another innovator is Columbia, whose Constitutional Court in 2017 declared the Atrato River a legal person, endowed with rights to its conservation and restoration. ${ }^{41}$ In a landmark judgement based on interpretation of the country's constitution, the Colombian Court sought to undo degradation of the Atrato River caused by illegal mining that government regulators had ignored. The case, brought

${ }^{37}$ Quoted in M. Safi, "Ganges and Yamuna Rivers Granted Same Legal Rights as Human Beings", The Guardian, 21 March 2017, www.theguardian.com/world/2017/mar/21/ganges-and-yamuna-riversgranted-same-legal-rights-as-human-beings.

${ }^{38}$ Te Awa Tupua (Whanganui River Claims Settlement) Act 2017, section 15(a) and (c).

39 "India's Ganges and Yamuna Rivers are "Not Living Entities"' BBC News, 7 July 2017, www.bbc.com/news/world-asia-india-40537701.

${ }^{40}$ R. Chandran, "Fears of Evictions as Bangladesh Gives Rivers Legal Rights", Reuters (5 July 2019), www.reuters.com/article/us-bangladesh-landrights-rivers/fears-of-evictions-as-bangladesh-givesrivers-legal-rights-idUSKCN1TZ1ZR.

41 See www.iucn.org/news/world-commission-environmental-law/201909/tour-save-worldcolombia-wins-yellow-jersey-rights-nature. 
by locally impact communities and the Center of Studies for Social Justice, resulted in the court mandating that the government appoint two protective representatives of the river, one from the community and another from the government. Consolidating this stance, in 2018 the Supreme Court of Colombia recognised a portion of the Amazon rainforest as a legal subject, with the concomitant duty placed on authorities to intervene to stop deforestation and associated environmental impacts. ${ }^{42}$ This case was initiated by a group of children and young adults who presented themselves to the court as representatives of the posterity most endangered by government inaction.

\section{RIGHTS OF NATURE IN AUSTRALIA}

Nature rights were first introduced in Australia, albeit only partially, in 2017 with enactment of: the Yarra River Protection (Wilip-gin Birrarung murron) Act - a law of the Australian state of Victoria. There been no further laws enacted since but considerable discussion about introducing rights of nature. ${ }^{43}$ The Australian Earth Laws Alliance (AELA) is the leading advocate for the recognition of nature rights, consisting of lawyers, academics, Aboriginal people and students. ${ }^{44}$ In the current political climate, it is inconceivable that Australia could emulate Ecuador or Bolivia's efforts because of the difficulty of amending its constitution that a plebiscite: only eight of 44 constitutional referendums in Australia have succeeded. ${ }^{45}$ Nature rights in Australia are thus more likely to propagate through legislation, especially via subnational law which has the advantage of defining smaller and discrete areas to benefit from nature rights. ${ }^{46}$

42 Ibid.

${ }^{43}$ E.g., M. Good, "The River as a Legal Person: Evaluating Nature Rights-based Approaches to Environmental Protection in Australia" (March 2013) National Environmental Law Review 1: 34; K. O'Bryan, "The Changing Face of River Management in Victoria: The Yarra River Protection (Wilip-gin Birrarung murron) Act 2017 (Vic)", (2018) 44(6-7) Water International 769.

${ }^{44}$ AELA, "About Us", www.earthlaws.org.au/about-us.

45 "Referendums" Australian Electoral Commission, 3 April 2020, www.aec.gov.au/Elections/referendums.

${ }^{46} \mathrm{M}$. Margil, "Building an International Rights of Nature Movement" in M. Maloney and P. Burdon (eds) Wild Law in Practice (Routledge, 2014), 149, 157. 
The Yarra River Protection (Wilip-gin Birrarung murron) Act 2017 combines a partial nature rights approach with conventional environmental planning in which the river is an object of legal management. The legislation does not explicitly recognise the Yara River as a legal person but it affirms the intrinsic values of the river as "one living and integrated natural entity"47 and, like New Zealand's approach, "recognises the intrinsic connection of the traditional owners to the Yarra River and its Country and further recognises them as the custodians of the land and waterway which they call Birrarung". ${ }^{48}$ Also significant, the Act establishes guardianship via the newly created Birrarung Council - the appointed "advocate for protection and preservation of the Yarra River"49 - coupled with a variety of statutory principles that emphasise Aboriginal cultural values including that "the role of the traditional owners as custodians of Yarra River land should be acknowledged through partnership, representation and involvement in policy planning and decision-making". ${ }^{50}$ These innovations co-exist with more familiar elements of environmental legislation, including a process to develop a strategic plan for the river, ${ }^{51}$ consult with the community, ${ }^{52}$ and make decisions with regard to well-established norms of environmental governance including the precautionary principle and intergenerational equity principle. ${ }^{53}$

Another recent Australian development is the Rights of Nature and Future Generations Bill, introduced into the Western Australian Legislative Council in 2019. Tabled as a private members bill by Greens parliamentarian, it was the first time that legislation had been formally proposed in Australia to explicitly affirm nature rights. The Bill's objects include recognising and securing the right of nature to "exist, flourish, regenerate, and evolve" and allowing for Western Australians and their government to defend those rights in court. ${ }^{54}$ It also recognises the rights of Aboriginal peoples, including to speak for their country and defend ancestral land and sea against

\footnotetext{
47 Section 1(a).

48 Preamble.

49 Section 5(6)(d).

50 Section 12(2).

51 Part 4.

52 Section 18(d).

53 Sections 9(1) and 8(4) respectively.

${ }^{54}$ Clause S3(1)(a).
} 
environmentally pernicious development. This Bill however is yet to pass - and appears unlikely to do so - although it marks a seminal step towards codifying how nature rights could be formalised in Australian legislation.

A variety of natural areas in Australia have been proposed for receiving rights. One is the Great Barrier Reef, which proponents hope will help control the myriad threats to it from mining and agricultural pollution. ${ }^{55}$ As the Reef is already listed under the World Heritage Convention 1972, ${ }^{56}$ the proposed nature rights for the Reef is premised on the need for a new approach offering high protection. One element of it could be to "reverse the onus of proof", namely: "where a person or community takes action to enforce the rights of the Reef, the new laws require the development proponents being challenged to prove that their project, activity, or development does not interfere with the rights of the Great Barrier Reef to exist, thrive, regenerate, and evolve". ${ }^{57}$ The beleaguered Murray-Darling Basin has also been mooted for nature rights. $^{58}$ The historic and continuing overuse of the Murray and Darling waters for farming and other human uses has caused severe environmental degradation, prompting some legal scholars to suggest the nature rights model as the best solution to revive and maintain the river basin. ${ }^{59} \mathrm{~A}$ third area in Australia proposed for nature rights is Tasmania's Tarkine region, the focus of this article.

\section{THE TARKINE WILDERNESS}

The Tarkine / takayna is a collection of diverse, wild ecosystems and Indigenous heritage land covering some 450,000 hectares of northwest Tasmania (see Figure 1). ${ }^{60}$ It contains the largest temperate rainforest in Australia, and the second largest such

55 AELA, "About the Rights of the Reef Campaign", https://rightsofnature.org.au/gbrcampaign/about-gbr-legal-rights.

${ }^{56}$ Convention Concerning the Protection of the World Cultural and Natural Heritage, 1 ILM 1358 (1972)

57 AELA, "About the Model Laws Recognising the Rights of the Reef" " https://rightsofnature.org.au/gbr-campaign/draft-laws-for-the-gbr/.

${ }^{58}$ Burdon, supra note 3.

59 Ibid.

60 J. Evans, Valuing the Tarkine: A Systematic Quantification of Optimal Land Use and Potential Conflict Compromise (Thesis, Institute for Regional Development and School of Land and Food University of Tasmania, October 2016) 3. 
biome in the Southern Hemisphere. ${ }^{61}$ The forests of myrtle, leatherwood and pine trees in the Tarkine are some of the last remaining traced to the ancient Gondwana super-continent. ${ }^{62}$ It harbours rare and endangered wildlife, including Tasmanian devils, wedge-tailed eagles, spotted-tail quolls, and the world's largest freshwater crayfish. $^{63}$

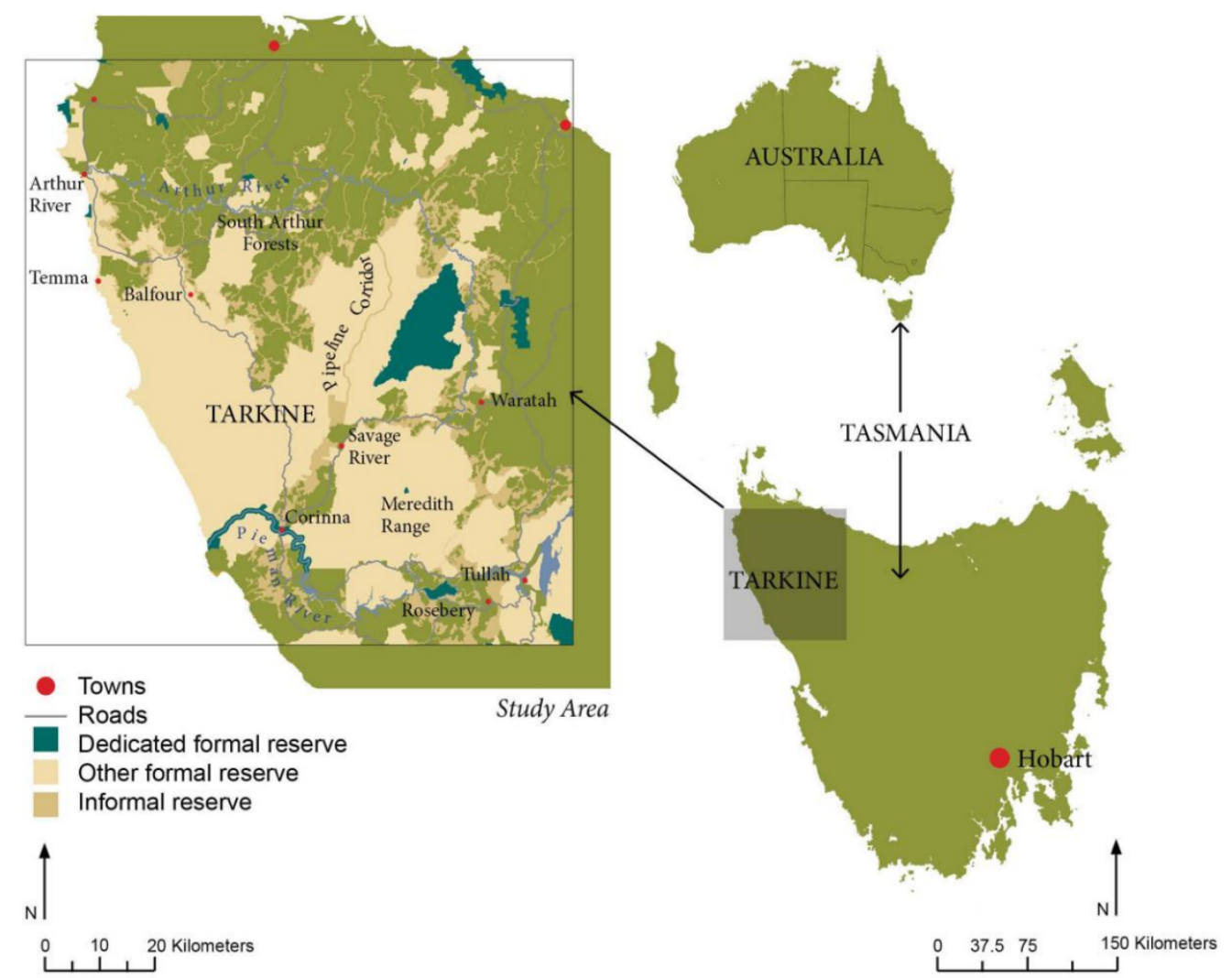

Figure 1: Tarkine region; map by Jennifer Evans, note 60.

The Tarkine has negligible human settlement today, although the wider northwest of Tasmania currently has 112,000 people with minimal population growth in an economically subdued region. It has a long history of human occupation by the Aboriginal tarkiner people, for some 40,000 years. ${ }^{64}$ A philosophy of kinship and

61 Ibid 2.

62 K. Croxford, "Drawing a Fine Line in the Tarkine" Inside Story, 6 September 2013, https://insidestory.org.au/drawing-a-fine-line-in-the-tarkine..

63 Bob Brown Foundation, www.bobbrown.org.au/takayna_tarkine.

${ }^{64}$ P. Pullinger and H. Sculthorpe, Takayna: Country, Culture, Spirit (Bob Brown Foundation, 2016). 
connection to country is vital to the tarkiner and other Indigenous (palawa people) of Tasmania, or lutruwita as known in their language. ${ }^{65}$ The palawa cared for the ecological systems of the land, understanding its natural cycles, weather patterns and needs. ${ }^{66}$ Since British colonisation in 1803 , the palawa have fought tirelessly for the right to self-determination, sovereignty and restorative justice, and in recent decades have been regaining recognition of their First Nations' status, such as through the Aboriginal Land Rights Act 1995 (Tas.). ${ }^{67}$

The Tarkine has some of the greatest concentrations of Aboriginal heritage sites in Australia, including rock shelters, burial grounds, shell middens and stone artefacts. ${ }^{68}$ Although the region's coastal strip is listed as national heritage (known as the Western Tasmania Aboriginal Cultural Landscape), ${ }^{69}$ and some discrete sites and objects are protected under the Aboriginal Heritage Act 1975 (Tas.), officially no Aboriginal-owned or managed land in the Tarkine exists. Further, no land rights claims have succeeded in Tasmania and none of the small parcels of land returned under the Aboriginal Land Rights Act 1995 (Tas.) include areas of the Tarkine. ${ }^{70}$ If legal rights of nature are considered for the Tarkine, the voices and interests of its Aboriginal people would need to be recognised.

65 Personal communication from Jamie Graham, Aboriginal Tasmanian and member of the Tasmanian Independent Science Council, 17 June 2020.

${ }^{66} \mathrm{lbid}$.

67 J. Evans, "Giving Voice to the Sacred Black Female Body in Takayna Country" in J. Liljeblad and B. Verschuuren (eds), Indigenous Perspectives on Sacred Natural Sites: Culture, Governance and Conservation (Routledge, 2019) 15, 17.

${ }^{68}$ Bob Brown Foundation, supra note 84.

${ }^{69}$ Commonwealth Department of Agriculture, Water and the Environment, Natural Heritage Places - Western Tasmania Aboriginal Cultural Landscape, www.environment.gov.au/heritage/places/national/western-tasmania.

70 Although two areas just north of the takayna have been returned to Aboriginal control: at Steep Island and Mount Cameron West. 


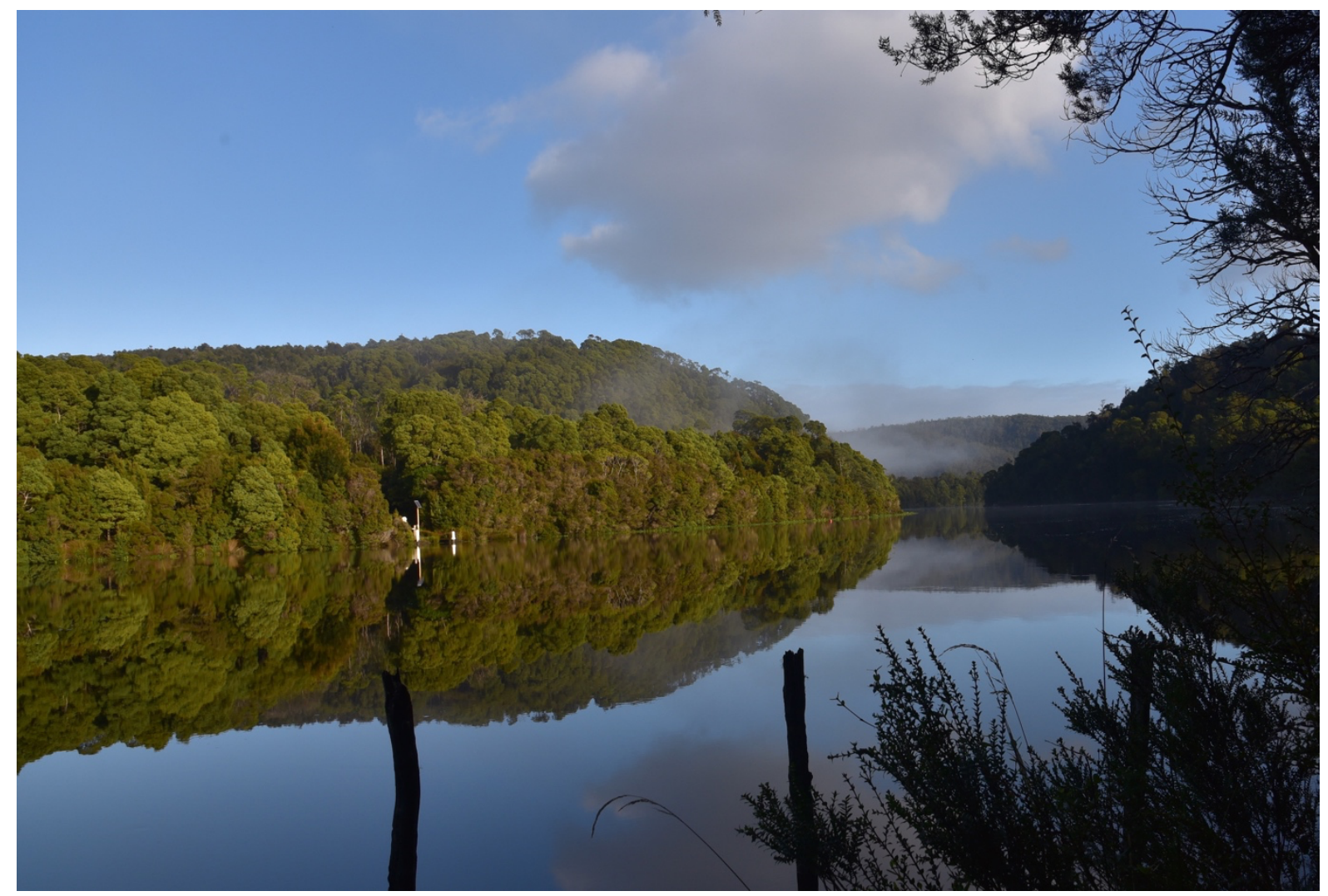

Figure 2: Pieman River, Tarkine, 2020; photo by author

\section{EXISTING GOVERNANCE OF THE TARKINE}

\section{Environmental Protection Measures}

As verified by the recent, 2020 review of Australia's principal environmental legislation - the Environment Protection and Biodiversity Conservation Act (EPBCA) 1999 (Cth) existing environmental laws in Australia are merely slowing ecological degradation rather than preventing harm or reversing past losses. ${ }^{71}$ The same can be said of Tasmanian environmental law. ${ }^{72}$ This article is not devoted to critiquing environmental law generally in Australia, rather focusing on governance most relevant to nature conservation in the Tarkine - though it illustrates broadly nationwide issues. Tensions

${ }^{71}$ Samuel, supra note 1 ; I. Lowe, "Wild Law Embodies Values for a Sustainable Future" in M. Maloney and P. Burdon (eds), Wild Law in Practice (Routledge, 2014), 3.

72 Tasmanian Planning Commission, State of the Environment Report: Tasmania 2009, (Tasmanian Planning Commission, 2009). 
between conservationists and government-sanctioned natural resource developers have long existed. Mining, hydro-power, forestry and aquaculture have driven deep political fissures in Tasmania's economy. These disputes are not unique to the Tarkine, but it has become the front-line for many. ${ }^{73}$ Attempts to grow tourism have also sometimes collided with nature conservation and Aboriginal interests.

The Tarkine is mostly public land, with 75 percent managed by the Tasmania Parks and Wildlife Service (TPWS). ${ }^{74}$ This estate includes state reserves, regional reserves, national parks, and other Crown reserves and private reserves offering variable environmental protection. ${ }^{75}$ Many are listed under the Nature Conservation Act 2002 and managed under the National Parks and Reserves Management Act $2002 .^{76}$ Despite such tenure, several governance gaps and weaknesses exist from a nature conservation perspective.

Firstly, extensive lands are open for environmentally damaging, extractive industries. About 19 percent of the region is held by the erroneously named 'Sustainable Timber Tasmania', and presently about one-quarter of this area is designated for current logging whilst the balance is held for future forestry production. ${ }^{77}$ Not only does logging deplete wilderness areas and remove or alter wildlife habitat, it creates a pathway for dissemination of diseases and increases risk of forest fires. ${ }^{78}$ Tasmania's climate change policy goals rely heavily upon forest carbon sinks to achieve net zero emissions by 2030 - a goal also jeopardised by some forms of logging. ${ }^{79}$ The latest three-year wood production plan of Sustainable Timber

${ }^{73}$ J. Evans, J. Kirkpatrick and K. Bridle, "A Reciprocal Triangulation Process for Identifying and Mapping Potential Land Use Conflict" (2018) 62 Environmental Management 777, 778.

Tasmanian Department of State Growth, "The Tarkine", www.stategrowth.tas.gov.au/_data/assets/pdf_file/0009/175815/The_Tarkine_Fact_Sheet_September_ 2018.pdf.

75 Land Information System Tasmania, "Listmap" Tasmanian Government, https://maps.thelist.tas.gov.au/listmap/app/list/map?fbclid=IwAR0J95pJUGwisftkcWspZIQdTrKgEv6Gs H7N5eV1sbw1OEFkmcUobSOJfOY.

76 "Reserve Listing" Tasmania Parks and Wildlife Services, https://parks.tas.gov.au/aboutus/managing-our-parks-and-reserves/reserve-listing.

77 Tasmanian Department of State Growth, supra note 74.

${ }^{78}$ Tarkine National Coalition, "Logging", www.tarkine.org/logging.

79 Tasmanian Climate Change Office, Climate Action 21: Report Card 2019, (Department of Premier and Cabinet, 2019). 
Tasmania, for $2020 / 21$ to $2022 / 23$ largely spares the Tarkine, but that is no assurance for the longer term. ${ }^{80}$

Forestry legislation offers relatively weak environmental protection. Logging is subject to limited environmental controls under the Forest Practices Act 1995 (Tas.) and the Tasmanian - Commonwealth Regional Forests Agreement (RFA), which exempts forestry operations from standard EPBCA controls. ${ }^{81}$ Covering all Tasmania, the RFA aims to provide long-term certainty for harvesters of native forests and a representative reserve system whilst limiting the application of EPBCA controls, notably its provisions for protection of threatened species. ${ }^{82}$ Tasmania's RFA, signed in 1997 and renewed in 2017 for two decades further, ${ }^{83}$ is being challenged in court by the Bob Brown Foundation because of the alleged failure to protect threatened species. ${ }^{84}$ Earlier litigation to prevent Forestry Tasmania (as Sustainable Timber Tasmania was then known) from logging the Wielangta forest resulted in the Federal Court ruling that such operations were exempt from the EPBCA. ${ }^{85}$ It held that relevant clauses in the Tasmanian RFA only obliged the establishment and maintenance of an adequate reserve system, which itself would constitute the protection of threatened species, without needing to demonstrate that the wildlife was in fact safe.

Significant tracts of the Tarkine are also open to mining, notably the large Savage River Mine, and as of June 2018, mineral tenements covered 36 percent of the region. The Mineral Resources Development Act 1995 (Tas.) and various state environmental legislation that regulates mining are deficient in the lack of comprehensive cost / benefit analysis applied to proposed mines, and inadequate post-mining remediation requirements that have left a costly legacy for Tasmanian

${ }^{80}$ Sustainable Timber Tasmania, Three Year Wood Production Plan: 2020/21 to 2022/23 (July 2020).

81 'Tasmanian Regional Forest Agreement between the Commonwealth of Australia and the State of Tasmania', Australian Government Department of Agriculture, Water and the Environment (1997).

${ }^{82}$ A. Macintosh and D. Wilkinson, "Best Practice Heritage Protection: Australia's National Heritage Regime and the Tarkine" (March 2012) 24(1) Journal of Environmental Law 75, 91.

${ }^{83}$ See www.agriculture.gov.au/forestry/policies/rfa/regions/tasmania.

${ }^{84}$ B. Brown, "Bob Brown Launches Legal Challenge to Native Forest Logging in Tasmania" The Guardian 21 August 2020, www.theguardian.com/australia-news/2020/aug/21/bob-brown-launcheslegal-challenge-to-native-forest-logging-in-tasmania.

${ }^{85}$ Forestry Tasmania v Brown [2007] FCAFC 186. 
taxpayers. Pollution from current mines has stirred considerable public criticism, as contaminated waste affects areas far beyond the mine sites. ${ }^{8687}$

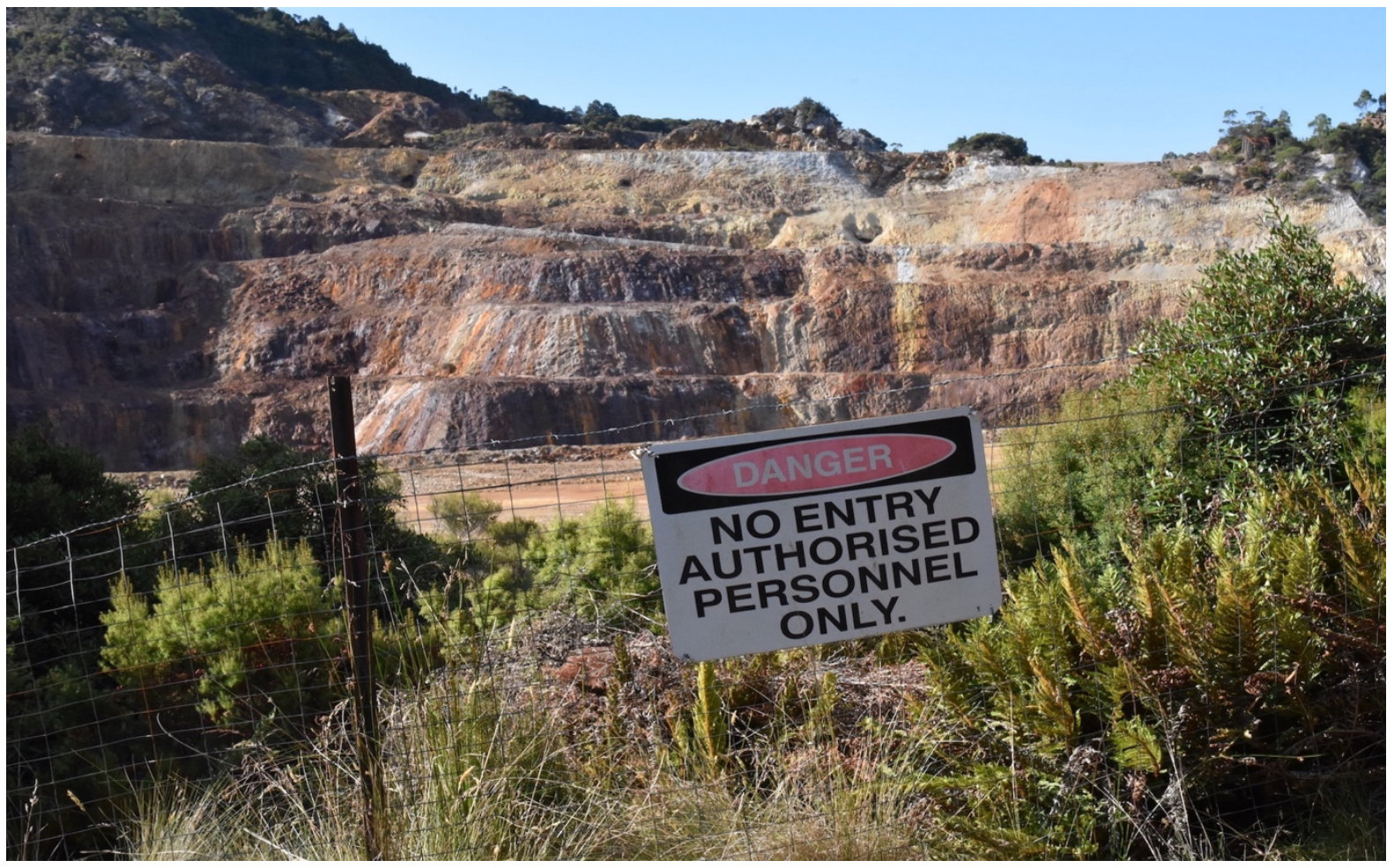

Figure 3: Former Bischoff mine, Tarkine (2018); photo by author

Extraordinarily, the majority of notional conservation reserves under the auspices of the TPWS are actually designated for multiple use, including mining and forestry. Each reserve class offers different levels of protection depending on its management objectives and statutory rules. ${ }^{88}$ The Arthur-Pieman Conservation Area, for instance, allows resource extracting, agriculture and four-wheel-vehicle recreational driving. ${ }^{89}$ By contrast, the 18,000 hectare Savage River National Park, established in 1999, is an inaccessible wilderness subject to high legal protection. ${ }^{90}$ For each reserve, the TPWS Director prepares a management plan, which can stipulate potentially allowable developments subject to further possible environmental

${ }^{86}$ E.g., J. Ryan, "Analysis: The Battle for Tasmania's Tarkine Wilderness", ABC Rural 6 August 2013, www.abc.net.au/news/rural/2013-08-06/mining-in-the-tarkine/4863892.

87 Tasmanian Department of State Growth, $\mathrm{n} 80$.

${ }^{88}$ Environmental Defenders Office (EDO), Environmental Law Hand Book, $\left(4^{\text {th }}\right.$ ed, 2014) 85.

${ }^{89}$ Evans, supra note 60. 16.

90 See https://parks.tas.gov.au/explore-our-parks/savage-river-national-park. 
assessment. ${ }^{91}$ Although management plans are open for public scrutiny and some offer protection for wilderness features, successive Tasmanian governments have been unwilling to foreclose extractive industries in the region.

Tasmania has an ignominious history of excising portions of its national parks for economic development. Despite given national park status in 1955, Lake Pedder was flooded in 1972 for inclusion in hydro-electric dam. ${ }^{92}$ Tasmania's first national park, established at Mt Field in 1916, likewise suffered partial revocation in 1950 to allow for logging, and subsequently 1300 hectares of its forests were cleared. ${ }^{93}$ Mineral exploration is also accommodated in the management objectives for existing Regional Reserves, Conservation Areas, Nature Recreation Areas, Public Reserves and Forest Reserves, although any approved mining should not conflict with their statutory management plans. ${ }^{94}$ Nor do private reserves under a conservation covenant provide comprehensive protection, as the government may approve mining on them. ${ }^{95}$

For the foreseeable future, little prospect exists that the Tasmanian government will strengthen legal protection for nature conservation in the Tarkine. In 2011 it vigorously opposed its nomination for the National Heritage List, made by the Tarkine National Coalition. The Australian government advised the Australian Heritage Council that such listing: "would have the effect of producing significant negative economic and social impacts on the community and economy of North- West Tasmania, and [...] would also significantly damage the future growth of the mining" and forestry sectors. ${ }^{96}$ The northwest of Tasmania has struggled economically for decades and has the state's highest unemployment rate and lowest household income. ${ }^{97}$ Furthermore,

${ }^{91} \mathrm{EDO}$, supra note 88.85.

92 K. Crowley, "Lake Pedder's Loss and Failed Restoration: Ecological Politics Meets Liberal Democracy in Tasmania" (1999) 34(3) Australian Journal of Political Science 409, 416.

${ }^{93}$ Kevin Kiernan, Conservation, 'Timber and Perceived Values at Mt Field, Tasmania' in J. Dargavel, De. Gaughwin and B. Libbis (eds), Australia's Ever-changing Forests V (Centre for Resource and Environmental Studies Australian National University, 2002) 209.

${ }^{94}$ EDO, supra note $88,85$.

95 V. Adams and K. Moon, "Mining is Digging the Heart Out of Conservation Covenants", The Conversation 29 May 2012, https://theconversation.com/mining-is-digging-the-heart-out-ofconservation-covenants-6588.

96 Tasmanian Government, Potential Socio-economic Implications for Tasmania of the Proposed National Heritage Listing of the Tarkine Area (October 2011), ,26.

97 Ibid, 4. 
because of the region's history of human activity, Tasmanian authorities reject associating the Tarkine with a "wilderness", arguing "it is extremely difficult to support the proposition that the whole area has heritage values". ${ }^{98}$

The Tarkine was granted Emergency National Heritage listing in December 2009 for 12 months by the then federal minister for the environment, Peter Garrett. In February 2013 the subsequent minister, Tony Burke, decided against including the entire Tarkine on the National Heritage list, instead choosing the much smaller but still significant portion known as the "Western Tasmanian Aboriginal Cultural Landscape". Burke's decision flouted the advice of the Australian Heritage Council. ${ }^{99}$ A National Heritage listing obliges authorities, by virtue of the EPBCA, to assess proposed developments for their potential impacts on the protected heritage values. ${ }^{100}$

At this juncture, we can determine that existing environmental governance of the Tarkine has serious weaknesses. Standing under the EPBCA is sufficiently broad to allow interested environmental groups or affected landholders to seek judicial review of virtually any government decisions pertaining to the Tarkine, but as the application of the EPBCA has been neutered owing to the Regional Forests Agreement, plus the limited Tarkine area included in the National Heritage List, recourse to judicial review of decisions under the EPBCA offers little benefits. Tasmanian environmental legislation itself is punctuated by various gaps and weaknesses, including that forestry operations are not subject to the state's Threatened Species Act 1995 (Tas.), and these gaps may be exacerbated by the new major projects legislation passed in 2020 that allows for significant development proposals to be approved outside the normal land use planning controls. ${ }^{101}$

\section{World Heritage Listing - A Better Option?}

Some Tasmanian conservationists propose the Tarkine for inclusion in the Tasmanian Wilderness World Heritage Area (TWWHA). It presently covers one-quarter of

\footnotetext{
98 Ibid, 25.

${ }^{99}$ Australian Heritage Council, Tarkine: National Heritage Values, ref B13/167 (2013),

100 EPBCA, sections $15 B$ and 137.

101 Land Use Planning and Approvals Amendment (Major Projects) Act 2020 (Tas.).
} 
Tasmania, and was listed under the World Heritage Convention in 1982, with further areas added in 1989, 2010, 2012 and 2013. ${ }^{102}$ As Australia has been an active party to this Convention, listing the Tarkine as a further extension of the TWWHA might offer a more politically feasible option that builds efficiently on an existing legal regime. The Convention mandates high-level protection of places accepted onto the World Heritage List (WHL) for their outstanding natural and/or cultural values. Whilst inclusion of a place on the WHL is decided by the United Nations World Heritage Committee, its nomination is decided by the nation-state in which the place is located. The Tarkine has been identified by researchers to have several of the ten outstanding universal values criteria for the $\mathrm{WHL}^{103}$ Additionally, as noted earlier, an assessment of the Tarkine by the Australian Heritage Council found the region has significant national heritage values. $^{104}$

World Heritage status imposes international responsibilities on the Australian government to protect listed places, although in practice their management is delegated to the state or territory in which they are situated - for the TWWHA, this is the Tasmania Parks and Wildlife Service. ${ }^{105}$ Therefore, it can be arduous to hold nations accountable for their performance, as decision making is their discretion within the broad framework set by the Convention. Australia's World Heritage areas are recognised as a "Matter of National Significance" under the EPBCA and therefore regulated by the Commonwealth. However, there are instances of the UN World Heritage Committee intervening; in 2013 the federal government under Prime Minister Tony Abbot proposed to remove 70,000 hectares of the TWWHA for forestry purposes but was blocked by the Committee's opposition. ${ }^{106}$ As this illustrates, the WHL adds another layer of internationally recognised intervention that Tasmanian-created

102 Department of Primary Industries, Parks, Water and Environment (DPIPWE), Tasmanian Wilderness World Heritage Area Management Plan (DPIPWE, 2016), 11.

${ }^{103}$ Macintosh and Wilkinson, supra note 82. 90.

${ }^{104}$ EDO, supra note 88. 90.

${ }^{105}$ A. Huggins, "Protecting World Heritage Sites from the Adverse Impacts of Climate Change: Obligations for States Parties to the World Heritage Convention" (2007) 14 Australian International Law Journal 121, 125.

${ }^{106}$ Australian Government, Response to the State Environment and Communications References Committee Report: Tasmanian Wilderness World Heritage Area (October 2014) 3. 
reserves and parks lack. The TWWHA has not suffered losses, such as that incurred with the Lake Pedder and Mt Field national parks in 1967 and 1950 respectively.

Yet, World Heritage properties are not entirely safe, as one example can illustrate. Despite warning from the World Heritage Committee to implement stricter regulation of tourism development within the TWWHA, ${ }^{107}$ the federal and state governments have yet to meaningfully do so. Ignoring the advice of the National Parks and Wildlife Advisory Council (TWWHA's independent expert advisory body), the Tasmanian government backed a commercial tourist development proposal at Lake Malbena to proceed without EPBCA assessment. ${ }^{108}$ It took two years of pressure from environmental groups, and their appeal to the Federal Court, for the federal government to agree to environmentally assess this development under the EPBCA. ${ }^{109}$ The Lake Malbena dispute emanates from a broader policy of the Tasmanian Liberal Party, governing the state since 2014, to expand tourism in Tasmania's parks and reserves, with the number of commercial leases there doubling between 2014 and 2020. ${ }^{110}$ Whilst the World Heritage Convention expects governments to promote public appreciation of listed properties, including through tourism, such promotion risks compromising the protected natural and cultural values.

There is also little that the Convention's governing bodies such as the World Heritage Committee can do to intervene in the ongoing management of a listed property even though it periodically reviews their management arrangements. So far 53 properties have been included by the Committee in its "List of World Heritage in Danger", 111 none of which are in Australia although the Great Barrier Reef has been

107 Tasmanian Wilderness (Australia) UNESCO decision 39 COM $7 \mathrm{~B} .35$ (2015) s5(c), https://whc.unesco.org/en/decisions/6290.

${ }^{108}$ B. Gogarty, N. Fitzgerald and P. McCormack, "Green Light for Tasmanian Wilderness Tourism Development Defied Expert Advice" The Conversation (16 October 2018), https://theconversation.com/green-light-for-tasmanian-wilderness-tourism-development-defiedexpert-advice-104854.

${ }^{109}$ A. Holmes, "Environment Minister Orders Assessment of Lake Malbena Proposal Under EPBC Act", The Examiner 17 September 2020, https://www.examiner.com.au/story/6929665/minister-ordersassessment-of-lake-malbena-proposal.

110 E. Baker, "The Tiny Island at the Heart of the Battle for Tasmania's Wilderness", ABC News, 22 February 2020, www.abc.net.au/news/2020-02-22/halls-island-at-heart-of-battle-for-tasmaniawilderness/11983556.

${ }^{111}$ World Heritage Convention, supra note 56, article 11(4). 
mooted for inclusion in this list (and also proposed for nature rights, as noted earlier). The aim of the list is to raise international awareness, encourage remedial action, and stall future damage, although taking effective action is ultimately a matter of the government concerned. Such action, however, would under the EPBCA be open to greater scrutiny, with environmental groups able to appeal to the courts for review of governments' decisions affecting a World Heritage property.

\section{INTRODUCING NATURE RIGHTS TO THE TARKINE}

The foregoing analysis suggests that introduction of the rights-of-nature model would improve current legal conservation of the Tarkine's natural and cultural heritage values. However, the extent of any such gain depends on how such rights are formulated. There is no archetype. As existing precedents examined in this article show, nature rights, like many types of environmental laws, can take a variety of guises of variable ambition and efficacy. Current Australian laws already in many cases give standing to any person or interested group to bring environmental cases before the courts, as would conceivably most rights-of-nature regimes. The key difference concerns what is actually protected. Of course, additional (ostensible) protection offered by nature rights may be a false gain if the resources and enforcement machinery are not available - a problem that afflicts considerable existing Australian environmental law.

If more of the Tarkine were proclaimed as a national park, that might result in environmental protection on par with some forms of nature rights. Tasmania's National Parks and Wildlife Management Act 2002 specifies that the management objectives for a national park include "to conserve natural biological diversity", "to encourage cooperative management programs with Aboriginal people" and "to preserve the natural, primitive and remote character of wilderness areas". ${ }^{112}$ Whether such goals are achieved would depend on the location of park boundaries, the content of management plans and the resources allocated for enforcement. A World Heritage listing for the Tarkine could deliver similar goals, with the benefit of the EPBCA overlay for additional accountability plus greater international scrutiny. Both legal options,

112 Schedule 1. 
however, are still premised on the protected nature as 'property'. ${ }^{113}$ In practical terms this might not make much difference compared to a rights-of-nature regime, but the latter would have significant symbolic value, which in turn could be harnessed for more stringent implementation of legal protections and heightened public vigilance.

Nature rights could be recognised for the Tarkine in several ways. ${ }^{114}$ These could include constitutional reform, federal and/or Tasmania environmental legislation or, less likely, judicial activism. The most politically feasible option would be to emulate the example of the Yarra River legislation, in which the distinctive natural and cultural values of the Tarkine are affirmed for protection and an independent entity tasked with fiduciary custodianship. The Yarra River model, as explained above, strives to recognise Aboriginal values and promote Aboriginal stewardship of the area. Whilst there is evidence of the synergy between Aboriginal culture and environmental stewardship, some international researchers caution against overstating this synergy - for instance, nature rights may not directly correlate with Indigenous worldviews about nature and may constrain Indigenous emancipatory aspirations. ${ }^{115}$

As outlined earlier, constitutional reform to introduce nature rights would likely flounder politically and, even if passed, the generality of any provision would not easily be able to target specific areas such as the Tarkine. Furthermore, given many diverse Indigenous communities across Australia, ${ }^{116}$ accurately incorporating their lore, perspectives and rights under a singular national reform would pose significant difficulties. National legislation could help elaborate such details, but the current political bias against greater Commonwealth leadership in environmental law makes this option unlikely in the near term. State-based regulations, although more specific and targeted, may lack resources to maintain and enforce the legal rights of Tarkine, and given the unsavoury history of Tasmanian politics, such rights could be vulnerable to adverse legislative changes.

${ }^{113}$ Margil, supra note 46, 158.

${ }^{114}$ Australian Centre for the Rights of Nature, "How Could Rights of Nature Laws be Created in Australia", https://rightsofnature.org.au/what-are-rights-of-nature.

115 M. Tanaescu, "Rights of Nature, Legal Personality and Indigenous Philosophies" ( (2020) Transnational Environmental Law, https://doi.org/10.1017/S2047102520000217.

116 "Who are Indigenous Australians?" Australians Together, https://australianstogether.org.au/discover/the-wound/who-are-indigenous-australians. 
A nature rights regime for the Tarkine should have more political appeal by recognising the environmental knowledge of the palawa Aboriginal people and their special affinity to the region. Following New Zealand's Te Urewera Act and elements of the Yarra River legislation, a board could be constituted of both government officials and members of the palawa to manage the Tarkine. Representation could extend to other stakeholders. including from leading environmental groups and the local, nonAboriginal community, though bringing in additional groups adds complexity to decision-making and risks generating more conflicts. An expert advisory panel to make assessments of proposed activities within the Tarkine could assist the board. Also, locus standishould be open to anyone to bring a claim to a court regarding breaches to the legislation and to hold both government and nongovernment actors accountable. The board itself would need to be obliged to be an advocate for the Tarkine and represent its interests in land use planning forums, taking action in court to defend it and to participate other legal process. Although this article has not discussed the financial and resourcing aspects for implementing nature rights, government funding, would be a necessary adjunct to any law reform.

When assessing the value of nature rights for the Tarkine, the wider context cannot be ignored, as it can undermine even the most ambitious rights regime. Accelerating climate breakdown, which already fuelled the massive bushfires that scorched 18 million hectares of Australia in the summer of 2019-20, could one day devastate the Tarkine as well. Affirming its legal personality would be a hollow victory if such devastating climate change is unabated. Although, stronger environmental protection for the Tarkine itself would improve its contribution to carbon sequestration and enhance the resilience of some wildlife to withstand adverse environmental changes. Relatedly, research shows that logging puts Australian forests at greater risk of burning than if they had been undisturbed. ${ }^{117}$ The Tarkine's rights should thus include the right to take action against industries and governments responsible for climate change, although this option would be unavailable against international actors because of Australian courts' lack of jurisdiction.

117 D.B. Lindenmayer, et al, "Recent Australian Wildfires Made Worse by Logging and Associated Forest Management" (2020) 4 Nature Ecology and Evolution 898. 
Tackling climate change and other long-range environmental threats to the Tarkine would require a composite of policies, and may necessitate a comprehensive "Green New Deal" to overhaul the economy. ${ }^{118}$ Nature-rights legislation cannot effectively protect discrete enclaves of the natural world if the wider forces driving environmental degradation are ignored: collateral, comprehensive economic and political reforms must put human society on a truly environmentally sustainable footing. In this guise, any nature rights for specific ecosystems, landscapes or other places should be complemented by a wider affirmation of the legal status of the natural world as an underpinning to the biosphere's prosperity. This suggests a need for a national or even global approach, but as already noted the political difficulties escalate at these higher governance scales.

The efficacy of legal rights of nature also depends on robust compliance and enforcement mechanisms. ${ }^{119}$ Even with legal personhood, nature's agency relies on the mediating role of enlightened human actors, whether they be concerned members of the general public or designated trustees mandated to act on behalf of the beneficiary natural place. Compliance mechanisms may range from a dedicated regulator charged with managing all activity that may materially affect the protected place to prescribed principles or standards of environmental protection that are then left for courts to uphold on application by any public or private party. As with existing precedents of nature rights, we do not suggest that legal rights for the Tarkine should prevent any and all developments within its region or to lock people out; rather, there must be a system which does stops dangerous development that would impair the Tarkine's integrity and ability to thrive indefinitely.

Given existing mining, forestry and agricultural activities in parts of the Tarkine, their presence must also be reconciled with introducing nature rights to the region. This circumstance reflects the reality that most environmental law reform has to accommodate existing uses - there is no blank slate to work from. ${ }^{120}$ These existing activities could hardly be closed overnight, given the political and economic difficulties.

118 N. Klein, On Fire: The (Burning) Case for a Green New (Penguin, 2019).

119 O'Donnell and Talbot-Jones, supra note 17.

120 Richardson, supra note 6 , 
Instead, a rights of nature regime would need transitional arrangements, such as allowing existing activities to remain for a period of years (e.g., one decade), and thereafter to implement environmental restoration coupled with economic adjustment for affected communities.

\section{INTERNATIONAL LESSONS}

Affirming the legal personality and rights of nature is a potentially significant milestone in the evolution of environmental law. It is too early to tell whether the existing legal precedents will prove to be largely symbolic gestures or practical game-changers. But given the dismal performance of most environmental regulation, we must urgently experiment with new approaches. Environmental scientists have joined legal scholars in making the case for the rights of nature; some have even proposed an equivalent of the Universal Declaration of Human Rights 1948 for the natural world. ${ }^{121}$

In conclusion, this article suggests the following important lessons for all countries to consider with nature rights law reform.

- First, rights of nature can be legally recognised by various routes. Although it has become a transnational movement, rights of nature have thus far been codified only in domestic law, without any international law status. No international legal obligation yet exists on any other nation to follow this legal precedent. This circumstance is unlikely to change for the foreseeable future.

- Second, the rights of nature can be formulated at different scales, from blanket application to an entire country (eg in Ecuadorian constitutional law) to a specific ecosystem or topographical feature (eg the Tarkine, or a river, as in New Zealand). In the latter situations, the question arises whether the lack of legal personhood for other natural environments implies they deserve less protection. Law reform would need to address that question explicitly.

- Third, the recipient environment may be described as a "legal person" with the full panoply of the incidents of legal status as far as relevant, or as a bundle of

${ }^{121}$ G. Chapron, Y. Epstein and J.V. Lopez-Bao, "A Rights Revolution for Nature" (2019) 363(6434) Science 1392. 
specific rights such as relating to conservation and restoration. Existing formulations of nature rights provide little guidance on what specific human activities and interventions are legally acceptable. Thus, important issues remain to be determined by the courts: for example, would control of species deemed to be pests be consistent with respecting the rights of a protected natural area, and could a forest be harvested for timber according to sustained yield standards? Such issues, in turn, raise the question of how far the content of rights of nature may differ from conventional environmental law standards such as those associated with the precautionary principle.

- Fourth, enforcement of such rights can be assigned to a specific guardian, such as a government agency or private group, or belong to an entire community. The framework for compliance control in turn is crucial for nature rights to be more than merely symbolic gestures. Open locus standi is crucial to allow any person to seek justice in the courts for breaches of nature rights.

- Fifth, in several cases the rights of nature have been formulated to dovetail with the culture and history of local communities, especially Indigenous peoples. This connection highlights that the nature rights model does not necessarily imply an absence of human presence, and indeed that protection of nature may go hand-in-hand with sustaining human communities affected by environmental change.

- Finally, the existing approaches do not yet attempt to alter the wider economic and political systems that fuel environmental degradation. Property tenure, markets, business corporations, economic growth policies and other drivers of environmental upheaval remain intact. Thus, rights of nature essentially suggest restrictions to specific developments that interfere with the integrity of natural places. The long-term viability of nature rights will depend on this reform being able to leverage wider policy and legal changes to put all societies on an ecologically sustainable footing.

This article has examined the conceptual foundations and emerging precedents for rights of nature. The Tarkine is a wild, relatively unadulterated region, with 
extraordinary cultural and natural value. Yet it remains exposed to harmful human exploitation. There are gaps and weaknesses with Tasmania's environmental regulations, which suggest that reliance on existing legal options for nature conservation would be a risky option for the Tarkine. World Heritage status would be more secure, and indeed it could possibly even co-exist with affirmation of the legal rights of Tarkine, depending on how such rights are formulated (relevantly, proposals for giving such rights to the Great Barrier Reef have not suggested removing its World Heritage status).

For now, the greatest barrier to affirming the nature rights of the Tarkine or anywhere else in the world is not one of imagination or legal precedent, for the nature rights revolution is underway globally. The principal barriers are lack of political will and the long-term challenge to go beyond affirming the rights of discrete enclaves of nature to wholesale changes in human life to dramatically reduce our ecological footprint. Perhaps adoption of rights of nature could trigger the necessary public awareness and political will to embrace this more ambitious agenda. 